\title{
Genotypic variability and risk factors of hepatitis $B$ virus in Western Siberia
}

\author{
Roman Bayandin ${ }^{*}$, Galina Kochneva', Galina Sivolobova ${ }^{1}$, Antonina Grazhdantseva', Sergei Netesov ${ }^{1,2}$ \\ From 15th International Conference on Human Retroviruses: HTLV and Related Viruses \\ Leuven and Gembloux, Belgium. 5-8 June 2011
}

In the study were included one group of acute hepatitis patients (1043 persons) of Barnaul's city hospital and four groups (500 persons in each group) of Novosibirsk's oblast inhabitants: medical staff, patients drug abuse clinic, AIDS center's patients, clinic patients applied for any disease. The frequency of HBsAg was: $3.6 \%$ in group of polyclinic patients, $5.4 \%$ of medical workers, $8.4 \%$ among drug abuse clinic's patients, $35 \%$ of AIDS center's patients and $36.5 \%$ of Barnaul's patients. Genotypes distribution was as follows: Novosibirsk oblast - 168 isolates of genotype D, 3 isolates of genotype A and genotype 2 isolates - C. In Barnaul: genotype D - 72 isolates, genotype A - 1. In the groups of Novosibirsk oblast the highest risk to be infected revealed for drug users $(\mathrm{OR}=6.75)$. The risk of seropositivity was increased among respondents who had more than 4 sexual partners during lifetime $(\mathrm{OR}=2.23)$; who had sex with HBV patients $(\mathrm{OR}=2.12)$; who spent at least one night at prison $(\mathrm{OR}=2.58)$. Risk factors also found for men $(\mathrm{OR}=1.85)$ and young people $(\mathrm{OR}=1.79)$ as those who are more inclined to risky behavior. The biggest risk factors in Barnaul were found among men who have sex with men $(\mathrm{OR}=8.79)$, person with $>2$ sexual partners in last 6 month especially in women $(\mathrm{OR}=5.15)$, those who $>30$ years $(\mathrm{OR}=4.51)$. High risk had person who had contacts with blood $(\mathrm{OR}=4.05)$. In Novosibirsk and Barnaul different medical operations such as surgery, blood transfusion, overall anesthesia weren't show itself as risk factors.

\section{Author details \\ 'State Research Center of Virology and Biotechnology "Vector", Koltsovo, Novosibirsk oblast, 630559, Russia. ${ }^{2}$ Novosibirsk State University, Novosibirsk, 630090, Russia.}

Published: 6 June 2011

\footnotetext{
* Correspondence: romb@ngs.ru

'State Research Center of Virology and Biotechnology "Vector", Koltsovo, Novosibirsk oblast, 630559, Russia

Full list of author information is available at the end of the article
}

doi:10.1186/1742-4690-8-S1-A211

Cite this article as: Bayandin et al:: Genotypic variability and risk factors of hepatitis B virus in Western Siberia. Retrovirology 2011 8(Suppl 1):A211.

Submit your next manuscript to BioMed Central and take full advantage of:

- Convenient online submission

- Thorough peer review

- No space constraints or color figure charges

- Immediate publication on acceptance

- Inclusion in PubMed, CAS, Scopus and Google Scholar

- Research which is freely available for redistribution

Submit your manuscript at www.biomedcentral.com/submit 